\title{
SEVENTY YEARS OF THE ANTHROPOLOGY SECTION OF THE ESTONIAN NATURALISTS' SOCIETY
}

\author{
(PART III) \\ Jaan Kasmel, Tiiu Kasmel \\ Centre for Physical Anthropology, University of Tartu, Tartu, Estonia
}

Part I of the current article, published in issue XVIII of Papers on Anthropology, gave a short characterization of the Estonian Naturalists' Society and viewed the emergence of its specialized subsidiary units. It described in detail, the foundation of the Anthropology Section in 1939 and the preceding period, 1853-1939, in the Society, assessed from the viewpoint of anthropology. Thereafter, the most essential facts were presented as excerpts from the annual reports of the Anthropology Section until the year 1994 (incl.) [12].

After the demise of Prof. J. Aul at the end of August of that year, the Section was headed by L. Heapost PhD who did it until April 2004.

The activities of the Anthropology Section in this period, presenting excerpts from the Section's annual reports, were dealt with in the second part of the article, which was published in the previous, XIXth issue of Papers on Anthropology [13].

To the meeting of the Anthropology Section on 21 April 2004, L. Heapost PhD, who had been Chair of the Section for nearly ten years, had submitted an application for resignation from the duties of the Chair of the Anthropology Section of the Estonian Naturalists' Society. After the approval of her application, the new chair was elected. Prof. H. Kaarma proposed that G. Veldre PhD, who had been secretary of the Section from 1996, should be elected as new Chair of the Anthropology Section. No other candidates were nominated. By open ballot, G. Veldre was unanimously elected Chair of the Anthropology Section. The meeting was attended by six members of the Section (L. Heapost, H. Kaarma, J. Kasmel, M. Lintsi, L. Saluste and G. Veldre) [1, 6]. 
The third part of the article will cover the events at the Anthropology Section under Gudrun Veldre's supervision until April 2009 when 70 years passed from the foundation of the Anthropology Section.

On 22 October 2004 the Anthropology Section held a research paper presentation meeting, Juhan Aul's Day, in the building of the Estonian Naturalists' Society. The meeting was dedicated to Juhan Aul's $107^{\text {th }}$ birth anniversary and the $65^{\text {th }}$ anniversary of the Anthropology Section.

The opening address was delivered by M. Sammul DBiol, President of the Estonian Naturalists' Society. Presentations were made by: J. Kasmel - On the beginning of anthropological research of Estonians; E. Jalakas (Estonian Academy of Security Sciences) - Relations between body build characteristics and physical abilities in students of the Estonian Academy of Security Sciences; G. Veldre - On the prospects of somatology when the Anthropology Section has reached its $65^{\text {th }}$ year; M. Saava (Estonian Institute of Cardiology) - On studies of the aged population in Tallinn.

Prof. H. Kaarma presented the new issue of the collection of articles Papers on Anthropology XIII, which had come out by J. Aul's birth anniversary. The collection included articles by Anthropology Section members L. Heapost, H. Kaarma, J. Limbo, M. Lintsi, and G. Veldre.

At the end of the meeting, a discussion arose about further trends in the work of the Section and about publicizing anthropological research, including the necessity for Internet and popular-scientific publications. President of the Estonian Naturalists' Society proposed that publications of the Society should be more actively used for issuing anthropological research papers.

The meeting had 20 participants.

Participation in international events:

1. At the conference dedicated to the $425^{\text {th }}$ anniversary of Vilnius University, 200 years of Lithuanian anthropology: modern trends, history, relation to medical practice and humanities in Vilnius from 2730 October 2004 presentations were made by:

R. Allmäe - Cremations in Western Estonia in V-XIII cc;

L. Heapost - The population of South-East corner of Estonia at the end of the iron age and in the middle ages;

J. Limbo - Dental enamel hypoplasia in the Pada cemetery (XII-XIII century). 
2. Section members L. Heapost and G. Veldre participated in the international conference dedicated to the $75^{\text {th }}$ birth anniversary of Academician V. P. Alekseev, Human ecology and demography in the past and at present, in Moscow from 14-17 November 2004. Because of organizational and information exchange problems, the main organizers of the conference had not received the abstracts of presentations from many participants, including the members of our Section, and, therefore, their presentations had been left out of the very dense programme of the conference.

From this conference, our Section members brought along a great number of anthropological research papers published in Moscow in recent years, including Horizons of Anthropology (Moscow, 2003) which includes L. Heapost's, H. Kaarma's and G. Veldre's articles based on their presentations at the eponymous international conference in $1994[1,6]$.

In 2005 the Anthropology Section held three meetings, one of them was a research paper presentation meeting:

The meeting that took place in the rotunda of the Old Anatomical Theatre (38 Lossi Street in Tartu) at 17:15 on 27 April had 11 participants: L. Heapost, H. Kaarma, J. Kasmel, L. Kiisk, M. Laurits, J. Limbo, M. Lintsi, V. Loolaid, L. Saluste, G. Veldre and I. Õnapuu. The meeting was chaired by G. Veldre.

There were the following items on the agenda: 1. Future prospects of the Anthropology Section - good ideas and concrete proposals were expected from all participants. 2. Prof. H. Kaarma - On organizing the work of the Anthropology Section at the international conference on the $200^{\text {th }}$ anniversary of the Old Anatomical Theatre (23-25 September). 3. Any other business.

At 15:00 on 20 October a research paper presentation meeting, Juhan Aul's Day was held in the building of the Estonian Naturalists' Society. The meeting was dedicated to Juhan Aul's $108^{\text {th }}$ birth anniversary.

The opening address was delivered by M. Sammul DBiol, President of the Estonian Naturalists' Society. Presentations were made by: J. Kasmel - On anthropological research in Estonia, Latvia and Lithuania from 1918 to 1940; Ü. Kirss - On predicting the weight and height of children aged up to two years; M. Lintsi - Impressions from the German anthropological congress in Munich in 2005; M. Toomsalu - 
Impressions from the jubilee conference of the Old Anatomical Theatre in 2005 in Tartu.

Prof. H. Kaarma presented the XIVth issue of the collection Papers on Anthropology which was the bulkiest of all published until then, containing 34 articles on 394 pages. Six articles had been written by the members of the Anthropology Section.

The meeting had 22 participants.

At 16:15 on 1 December, the meeting summarizing the activities of the Anthropology Section in 2005 was held in Room 301 at Vanemuise 46.

The meeting had 9 participants: L. Heapost, H. Kaarma, J. Kasmel, M. Laurits, J. Limbo, M. Lintsi, L. Saluste, G. Veldre and I. Õunapuu.

The agenda included: 1. Short summaries by Anthropology Section members on their main activities in 2005. The presenters were: H. Kaarma (On the situation of the Anthropometric Register); L. Heapost (On the conference in Pskov and on paleodemography); J. Limbo (On using the enamel defects or hypoplasia caused by childhood metabolic stress in anthropology - The case of the Pada skeletal series); L. Saluste and G. Veldre (Impressions from the conference in Minsk). 2. Planning the work of the Anthropology Section for 20063. Any other business.

That year, the Anthropology section also presented a project for anthropological research of the inhabitants of Pärnu in 2006.

On 22 September, during the events of the Car-free Day organized by the Tartu Environmental Education Centre, M. Lintsi and G. Veldre participated in the work of the Health Corner in Küüni Street in Tartu. They measured people's height and body mass, calculated their body mass index and body fat content and measured their blood pressure.

Participation in international events:

1. Oral presentations were made at the international theoretical and practical conference Genetic and morphological markers in anthropology, criminalistics and medicine in Minsk from 15-17 June 2005: L. Heapost - Variability of Estonians' height from the $12^{\text {th }}$ to the $20^{\text {th }}$ century; L. Saluste - Comparison of standards of height, weight and BMI for adult populations of Estonia and Belarus; G. Veldre Somatotypes and arterial blood pressure in Estonian children aged 1215 years. 
L. Heapost's presentation attracted great attention at the plenary session of the conference. The texts of the presentations will be published in the conference collection.

2. The international conference Tissue Biology dedicated to the $200^{\text {th }}$ anniversary of the Old Anatomical Theatre in Tartu from 23-25 September 2005, also had an anthropology section (in Biomedicum, Ravila 19-1024 on 24 September). There were participants from Estonia, Latvia, Lithuania, Hungary and Germany. Nine presentations were made, among them four presentations by the members of the Anthropology Section of the Estonian Naturalists' Society.

The conference considered it necessary to organize such conferences regularly (biannually in different Baltic states) [2, 7].

In 2006 the Anthropology Section held four meetings, two of them were research paper presentation meetings.

At the meeting of the Anthropology Section of the Estonian Naturalists' Society in Room 301 at 46 Vanemuise Street at 13:15 on 25 January, guest speaker Prof V. Tillmann delivered the lecture How does the child grow? Different aspects of short-term growth. The presenter was asked a number of questions and the lecture was followed by a lively discussion around the coffee table. The meeting had 14 participants.

At 14:00 on 13 March, the exhibition Leiu Heapost 70 was opened at F. Puksoo Gallery in Tartu University Library. The exhibition was supported by the Estonian Cultural Endowment. The opening of the exhibition was followed by a research paper presentation meeting in the building of the Estonian Naturalists' Society (2 Struve Street).

At the opening of the exhibition M. Viikmaa made a presentation on L. Heapost's works.

In the building of the Estonian Naturalists' Society the following presentations were made: J. Kasmel - Graduation theses on Estonian school students physical development supervised by Prof. Juhan Aul; J. Limbo - Dental pathologies in pit grave Pada cemetery and votic grave Jõuga cemetery in Northeast Estonia; R. Allmäe - On funeral traditions in Läänemaa and Setumaa Counties.

There were 34 people listening to the presentations. Ten more people participated at the opening of the exhibition. 
At 15:00 on 20 October, the Anthropology Section of the Estonian Naturalists' Society and the Centre for Physical Anthropolgy at the University of Tartu arranged a research paper presentation meeting, Juhan Aul Day, in the building of the Estonian Naturalists' Society. The meeting was dedicated to Juhal Aul's $109^{\text {th }}$ birth anniversary. The meeting had 27 participants.

The collection Papers on Anthropology XV had come out; it included 27 articles on 320 pages; among them seven articles were by members of the Estonian Naturalists' Society.

The Section meeting at 16:00 on 18 December on the premises of the Centre for Physical Anthropology in the Old Anatomical Theatre (38 Lossi Street in Tartu) discussed the events of the bygone year and the plans for the beginning year. The meeting had eight participants.

It was decided to hold the first meeting of the Section in 2007 in the third week of January.

At the interdisciplinary conference of medical anthropology MEDICA III: The alien becomes familiar in the hall of the Estonian Literary Museum on 10-11 May, Jaan Kasmel made two oral presentations; both co-authored by T. Kasmel - On studies of Estonian school students' physical development in the town of Tartu and the districts of Tartu and Elva (now Tartu County) from 1956-1958 and On folk medicine at Baltic conferences of history of science from 19581959.

At the conference Tartu University History Museum 30 from 5-6 December, J. Kasmel made three oral presentations.

During the events of the Car-free Day organized by Tartu Environmental Education Centre on 22 September, L. Saluste and G. Veldre participated in the work of the Health Corner in Küüni Street in Tartu. They measured people's height and body mass, calculated their body mass index and body fat content and measured their blood pressure.

Participation in international events:

1. At the XIII Congress on Nutrition and Metabolism in Renal Disease in Merida (Mexico) from 28 February to 4 March, L. Kiisk made the presentation Nutritional Status in Kidney Transplant Patients (co-authors M. Lintsi, S. Mesikepp, E. Seppet, L. Saluste, Ü. Pechter and M. Ots).

2. At the IVth international conference of students Проблемь культурогенеза и древней истории Восточной Европь и Сибири (Problems of genesis of culture and ancient history of Eastern Europe 
and Siberia) in St. Petersburg from 27-30 April J. Limbo made the presentation Dental caries in pit grave Pada cemetery $\left(12^{\text {th }}-13^{\text {th }} \mathrm{cc}\right.$.) and votic grave Jouga cemetery $\left(12^{\text {th }}-16^{\text {th }} \mathrm{cc}\right.$.) in Northeast Estonia.

3. At the $2^{\text {nd }}$ international conference Aктуальные проблемы спортивной морфологии и интегративной антропологии (Tорісаl problems of sports morphology and integrative anthropology) at Moscow University from 29-30 May L. Saluste participated with the poster presentation Сравнительный анализ телосложения 50-летних мужчин сельской местности о. Хийумаа (Эстония) и Гресторпа (Швеция) (Comparative analysis of body build of 50-year-old men in a rural area in Hiiumaa Island (Estonia) and Grästorp (Sweden)) (coauthors G. Veldre, J. Peterson, M. Lintsi, H. Kaarma, M. Aunapuu, A. Arend, T. Hedner, M. Viigimaa).

4. At the $15^{\text {th }}$ Congress of the European Anthropological Association in Budapest from 31 August to 3 September, Man and Environment: Trends and Challenges in Anthropology, G. Veldre made the oral presentation Blood pressure differences in adolescents with various body build; J. Limbo made the poster presentation Dental pathologies from two skeletal populations of different burial customs from the end of Iron Age / Early Medieval in Northeast Estonia, and R. Allmäe (coauthors L. Maldre and M. Aun) made the poster presentation Iron Age cremations in South-Eastern Estonia.

5. J. Kasmel participated at the XXII Baltic Conference on the History of Science in Vilnius and Kaunas from 5-6 October where he was engaged in eight oral presentations $[3,8]$.

In 2007 the Anthropology Section celebrated several major anniversaries.

On 23 April, in cooperation with the Institute of History at Tallinn University and the non-profit association Archaeology Centre a Research Day and exhibition Karin Mark 85. 55 years of anthropology at the Institute of History was organized.

The selection of exhibits and arrangement of the exhibition was led by Anthropology Section members L. Heapost, R. Allmäe and J. LimboSimovart.

At the Research Day presentations were made by L. Heapost - On $K$. Mark's role in Estonian anthropology and J. Limbo-Simovart On 
odontology at the Institute of History now and its further trends of development.

The Research Day had more than 35 participants.

From 15-16 October, the Centre for Physical Anthropology and the Institute of Anatomy at the University of Tartu arranged an international anthropological conference dedicated to the $110^{\text {th }}$ birth anniversary of Juhan Aul (1897-1994).

For the time of the conference, the major part of Karin Mark's $85^{\text {th }}$ birth anniversary exhibition was brought from the History Institute of Tallinn University to the Old Anatomical Theatre in Tartu where it was put up next to the Medical Collections of the Faculty of Medicine.

With the help of the working team of the Medical Collections of the Faculty of Medicine (M. Toomsalu and others), exhibits were also displayed in honour of Prof. J. Aul's $110^{\text {th }}$ birth anniversary.

At the opening session of the conference at 10:00 on 15 October presentations were made by three members of the Anthropology Section: J. Kasmel - An overview of Juhan Aul's biography, L. Heapost - Memories about working with Juhan Aul, and G. Veldre - Assessment of physique peculiarities of the human body.

At the afternoon session of 15 October at the Old Anatomical Theatre, M. Lintsi made the presentation Foundation of the Anthropology Section of the Estonian Naturalists Society.

Together with conference guests, a wreath was taken to the grave of Juhan Aul, the founder of the Anthropology Section of the Estonian Naturalists' Society, at Raadi cemetery.

Approximately 40 people participated in the work of the conference.

By the beginning of the conference, the collection Papers on Anthropology XVI came out; it included 26 articles on 292 pages; among them five articles by members of the Estonian Naturalists' Society.

After Internet correspondence, the Section members decided to hold the meeting summarizing the activities of the Anthropology Section in 2007, which was planned for December, early in the following year.

At 16:00 on 18 December a Christmas gathering was arranged on the premises of the Centre for Physical Anthropology in the Old Anatomical Theatre (38 Lossi Street in Tartu). It was attended by five members of the Section.

At the seminar Interdisciplinary approaches to studying past events at Waide motel (near Elva in Tartu County) from 16-17 December 2007, R. Allmäe and J. Limbo-Simovart made a joint presentation 
Methods of physical anthropology in interpreting skeletal populations (the case of St. John's Church in Pärnu).

Participation in international events:

\section{A - symposiums, conferences, congresses:}

1. At the international symposium Rank, gender and society around the Baltic 400-1400 in Kuressaare from 23-27 May, J. Limbo-Simovart made the presentation Sex differences in Late Iron Age Northeast Estonia as indicated in dental pathologies and enamel hypoplasia.

2. On 2 June G. Veldre made an oral presentation as an invited guest at the $6^{\text {th }}$ scientific conference Advances in the assessment of physical development disorders in Warsaw - Estonian Experiences in Assessment of Physique Peculiarities in Adolescents.

3. At the international theoretical and practical conference Актуальные проблемь физической и сочиокультурной антропологии (Topical questions of physical and sociocultural anthropology) in Minsk from 19-21 June, oral presentations were made by L. Heapost Этнокультурный фон антропологического формирования юговосточных эстониев в 11-15 вв (Ethnocultural background to the anthropological formation of Northeast Estonians in $11^{\text {th }}-15^{\text {th }}$ centuries) and G. Veldre - Blood pressure differences in Estonians with various body build - some preliminary data of HYPEST study.

L. Saluste (co-authors H. Kaarma, M. Lintsi, S. Koskel, A. Arend) made a poster presentation (in Russian) - Estonian national norms of height, weight and body mass index for men and women aged 20-70 years.

4. At the conference of Russia's ethnologists and anthropologists in Saransk from 9-14 July, L. Heapost made the presentation On the ethnocultural background of the anthropological formation of SE Estonians in the $11^{\text {th }}-15^{\text {th }} \mathrm{cc}$.

5. At the international conference in Vilnius, Anthropology and Medical Practice, G. Veldre made the oral presentation Bivariate body height-weight classification, a useful tool in systematization and analysis of medical data.

6. At the $4^{\text {th }}$ Conference of Baltic Morphologists in Riga from 19-20 November, members of the Anthropology Section made two oral presentations: H. Kaarma, co-authors L. Saluste, G. Veldre, E.-M. Tiit Prospects for studies of body build and nutritional habits in Estonia; J. Kasmel, co-author T. Kasmel - On the beginning of systematic 
anthropological research at the University of Tartu (the former Imperial University of Dorpat).

J. Kasmel also made a poster presentation, co-author T. Kasmel Professor Juhan Aul as an anthropologist (for the $110^{\text {th }}$ birth anniversary of Prof. J. Aul).

\section{B - upgrading of qualification, advanced training courses:}

1. On 17 January R. Allmäe and J. Limbo-Simovart visited the departments of archaeology and forensic medicine at Museovirasto (Finland's National Board of Antiquities) and the University of Helsinki where they acquainted themselves with preservation of osteological and archaeological collections, excavation methods of mass graves and forensic medical methods in osteology.

2. From 6-17 August R. Allmäe studied the methods of determination of osteological age and paleodemographic analysis at the Summer University in Odense which was arranged in cooperation between the Max Planck Institute for Demographic Research (MPIDR) and Department of Anthropology (ADBOU), (Institute of Forensic Medicine, University of Southern Denmark, Odense).

3. From 17-28 September R. Allmäe and J. Limbo-Simovart participated in organizing the short course Bioarchaeology - opportunities for interpretation of life and lifestyle of the people of the past at the Department of Archaeology at Tallinn University. The international short course was arranged in cooperation with the Universities of Tartu (M. Konsa, V. Lang) and Vilnius (R. Jankauskas) [4, 9].

In 2008 the Anthropology Section held three meetings, two of which were research paper presentation meetings. For the first time, one of the meetings was held using the mediation of the Internet (Skype).

By 16:00 on 15 February, eight members of the Anthropology Section residing in Tartu had gathered into one of the buildings of Tartu University Hospital (Room 208 at 8 Puusepa Street in Tartu). Simultaneously, three members of the Section residing in Tallinn had gathered into J. Limbo-Simovart's office at the Department of Archaeobiology and Ancient Technology at the Institute of History at Tallinn University (at 6 Rüütli Street in Tallinn). The reason for such a gathering was the decision of the Section to use Skype for holding its 
meeting. This made it possible to hold the meeting without some members of the Section travelling from Tallinn to Tartu.

The agenda of the meeting was as follows: summary of the activities of the Anthropology Section in 2007 (after the introduction by Chair of the Section G. Veldre, all participants took the floor); election of the board of the Anthropology Section (according to the Section's rules of procedure); discussion of the question whether the rules of procedure of the Anthropology Section should be changed considering the further activities of the Section; drawing up the work schedule of the Anthropology Section for 2008; any other business.

According to the election results, no changes were made in the board. The meeting found that it was possible to continue the Section's activities without changing its rules of procedure; still there should be more variety in the activities of the Section so that they would include more activities stipulated by the rules of procedure.

On 24 March, in cooperation with the Institute of History at Tallinn University and the non-profit association Archaeology Centre, the Anthropology Section arranged the Research Day dedicated to Karin Mark's $86^{\text {th }}$ birth anniversary Physical anthropology. The second Research Day at the Institute of History (in Room 307 at 10 Rüütli Street in Tallinn).

From the five presentations on the agenda tree were made by Anthropology Section members: L. Heapost - Analysis of the osteological material of Vôllamägi mass grave (6 Ravi Street in Tallinn); R. Allmäe. Methods of physical anthropology in interpreting skeletal populations (the case of St. John's Church in Pärnu); J. LimboSimovart - Methods of physical anthropology in interpreting skeletal populations (the case of St. John's Church in Pärnu). Odontological analysis.

The presentations were followed by an excursion to the Archaeology Museum of the Institute of History and a discussion around the coffee table. The Research Day had 13 participants.

At 15:00 on 16 October a research paper presentation meeting, Juhan Aul Day, was held in the building of the Estonian Naturalists' Society. The meeting was dedicated to Juhan Aul's $111^{\text {th }}$ birth anniversary.

The opening address was delivered by T. Viik, President of the Estonian Naturalists' Society. Presentations were made by J. Kasmel 15 years of the Centre for Physical Anthropology; M. Lintsi - Heino 
Tiik 75; M. Toomsalu - Medical collections as communicators of health awareness.

Prof. H. Kaarma presented the collection Papers on Anthropology XVII, which contained 25 articles on 339 pages. Among them, there were eight articles by the members of the Anthropology Section:

\section{The meeting had 23 participants.}

At 15:00 on 17 December, a Christmas gathering was held on the premises of the Centre for Physical Anthropology in the Old Anatomical Theatre (38 Lossi Street in Tartu). It was attended by six members of the Section.

On 26 September at the opening conference of the series of lectures Pärnu throughout centuries, R. Allmäe and J. Limbo-Simovart made a joint presentation Pärnu garrison - its origin and living conditions.

\section{Participation in international events:}

1. At the $16^{\text {th }}$ Congress of the European Anthropological Association in Odense (Denmark) from 28-31 August, R. Allmäe made the presentation Pärnu garrison and its varied origin and was the co-author of the presentation made by R. Jankauskas and G. Gerhards - Bioarchaeology - research and public presentation in the Baltic states. J. Limbo-Simovart made the presentation Dental enamel hypoplasia in the $17^{\text {th }}-18^{\text {th }}$ cc. town population from Pärnu, Estonia. The abstracts of presentations were published.

2. At the conference of the Association for Environmental Archaeology (AEA) in Arhus (Denmark) from 12-14 September, R. Allmäe made the presentation Role of fire in burial customs on the basis of two Iron Age burial places in Estonia. The abstract of this presentation was also published.

3. At the national conference in Russia Aдаптация как фактор формирования антропологического своеобразия (Adaptation as a factor in formation of anthropological peculiarities) in Moscow from 89 December, J. Limbo-Simovart made the presentation Dental pathologies and stressmarkers in the Iron Age End/Early Medieval Estonia and L. Heapost - Изменчивость цвета глаз и волос у финно-угорских народов (Variation of eye and hair colour in Finno-Ugric peoples).

The abstracts of both presentations were published in the conference collection $[5,10]$. 
In 2009 the Anthropology Section celebrated its $70^{\text {th }}$ anniversary with several events during the whole year.

On 23 March, the Anthropology Section, in cooperation with the Institute of History at Tallinn University, arranged a Research Day dedicated to Karin Mark's $87^{\text {th }}$ birth anniversary (in the large hall at 6 Rüütli Street). Presentations were made by M. Viikmaa - On determination of sex in animals and P. Hõrak - Sexual selection in humans.

The Research Day had approximately 30 participants [11].

As the Anthropology Section had its $70^{\text {th }}$ anniversary at the end of April 2009, and the report of the Section's activities for that year does not include any more events during the first four months of the year, the overview of the activities of the Anthropology Section during its seventy years has reached its end.

An overview of events at the Anthropology Section until the end of 2009 will be presented in the future together with its activities in the following years.

We are thankful to Chair of the Anthrology Section Gudrun Veldre DBiol who kindly allowed us to use the reports of the activities of the Anthropology Section from 2004-2008 for writing the third part of this article.

\section{REFERENCES}

1. ELUSi antropoloogiasektsiooni tegevuse aruanne 2004. aasta kohta.

2. ELUSi antropoloogiasektsiooni tegevuse aruanne 2005. aasta kohta.

3. ELUSi antropoloogiasektsiooni tegevuse aruanne 2006. aasta kohta.

4. ELUSi antropoloogiasektsiooni tegevuse aruanne 2007. aasta kohta.

5. ELUSi antropoloogiasektsiooni tegevuse aruanne 2008. aasta kohta.

6. Eesti Looduseuurijate Seltsi Aastaraamat. 83. köide. (2005) Tallinn, 267-269.

7. Eesti Looduseuurijate Seltsi Aastaraamat. 84. köide. (2006) Tartu, 322 324.

8. Eesti Looduseuurijate Seltsi Aastaraamat. 85. köide. (2008) Tartu, 255.

9. Eesti Looduseuurijate Seltsi Aastaraamat. 85. köide. (2008) Tartu, 263.

10. Eesti Looduseuurijate Seltsi Aastaraamat. 86. köide. (2011) Tartu, 284 285. 
11. Eesti Looduseuurijate Seltsi Aastaraamat. 86. köide. (2011) Tartu, 295297.

12. Kasmel J., Kasmel T. (2009). Seventy years of the Anthropology Section of the Estonian Naturalists' Society. Papers on Anthropology XVIII. Tartu, 14-38.

13. Kasmel J., Kasmel T. (2010). Seventy years of the Anthropology Section of the Estonian Naturalists' Society (Part II). Papers on Anthropology XIX Tartu, 21-28.

\section{Address for correspondence:}

Jaan Kasmel

Centre for Physical Anthropology

38 Lossi Street, Tartu 51003, Estonia

E-mail: jaanjkasmel@hot.ee 